\title{
PREDIKSI KANDUNGAN PATI PEPAYA IPB9 SELAMA PENYIMPANAN DENGAN SPEKTROSKOPINIR
}

\author{
Nur Arifiya \\ Teknik Industri, Universitas Indraprasta PGRI Jakarta \\ fifi.arifiya@gmail.com
}

\begin{abstract}
Abstrak
Parameter kualitas buah pepaya saat matang adalah kandungan pati, total padatan terlarut, dan kadar air, namun harus dilakukan analisis kimia yang bersifat destruktif dan membutuhkan waktu lama. Metode spektroskopi NIR merupakan sebuah metode nondestruktif, akurat, cepat, dan dapat menggantikan metode kimia yang mengkonsumsi waktu lebih lama. Dengan demikian tujuan penelitian ini untuk memprediksi kandungan pati, total padatan terlarut, dan kadar air dengan spektroskopi NIR. Penelitian ini menggunakan pepaya varietas IPB 9 sebanyak 60 buah dengan 3 ulangan, pengukuran dilakukan pada bagian pangkal, tengah, dan ujung buah. Kandungan pati dapat diprediksi dengan baik oleh spektroskopi NIR dengan pra perlakuan kombinasi msc dan $\mathrm{dg}_{1}$, ditunjukkan oleh model yang dihasilkan dengan nilai R, SEC, SEP, CV, dan RPD berturut-turut sebesar 0.90, 0.17 $\%, 0.16 \%, 10.95 \%$, dan 2.15. Nilai total padatan terlarut juga dapat diprediksi dengan baik oleh spektroskopi NIR dengan pra perlakuan msc diperoleh nilai R, SEC, SEP, CV, dan RPD berturut-turut sebesar $0.90,0.124 \%, 0.123 \%, 4.85 \%$, dan 2.27. Begitu pula nilai kadar air dapat diprediksi dengan baik oleh spektroskopi NIR dengan pra perlakuan dg1 diperoleh nilai R, SEC, SEP, CV, dan RPD berturut-turut sebesar 0.84, $0.03 \%, 0.04 \%, 0.43 \%$, dan 1.85 .
\end{abstract}

Kata kunci :Spektroskopi NIR, PLS,Pepaya

\begin{abstract}
The parameters of ripe papaya quality consisting of starch content, total soluble solid and water content must be measured by conductinga time-consuming and destructivelychemical analysis. NIR spectroscopy isa non-destructive, accurate, fast methodthat can substitute the such chemical analysis. This study aims to predict starch content, total soluble solid, and water content using NIR spectroscopy. 60 pieces ofpapaya of IPB 9 varietyat the part of top, middle, and bottom was measured with 3 replications. Starch content can be well predicted by NIR spectroscopy with pre-treatment of combination between msc and dgl, as indicated by the model generated by the R, SEC, SEP, CV, and RPD of 0.90, 0.17\% 0.16\%, 10.95\%, and 2.15 respectively. Total soluble solid can bewell predicted by NIR spectroscopy with pre-treatment msc R, SEC, SEP, CV, and RPD, as indicated by 0.90, 0.124\%, 0123\%, $4.85 \%$, and 2.27 respectively. Similarly, the water content can be well predicted by NIR spectroscopy with pre-treatment dg1 R, SEC, SEP, CV, and RPD, as indicated by 0.84, $0.03 \%, 0.04 \%, 0.43 \%$, and 1.85 respectively.
\end{abstract}

Keywords : NIR Spectroscopy, PLS, Papaya

\section{Pendahuluan}

Pepaya merupakan buah klimaterik yang masih dapat mencapai puncak klimaterik meski buah sudah dipanen.Pepaya banyak dikonsumsi oleh masyarakat Indonesia, baik dalam keadaan segar ataupun belum matang. Dalam (Tirkey, dkk, 2014)menyatakan bahwa pada umumnya pepaya dikonsumsi dalam bentuk pepaya matang segar karena banyak mengandung vitamin $\mathrm{C}$ dan vitamin A. Salah satu masalah buah dalam kondisi segar adalah kerusakan dan penurunan kualitas yang sangat cepat terjadi, sehingga perlu adanya upaya untuk mempertahankan kualitas produk lokal. Upaya yang dilakukan untuk menyaingi buah pepaya impor adalah dengan mengembangkan varietas baru yakni varietas pepaya IPB 9 yang dikeluarkan oleh Institut Pertanian Bogor dengan nama pasar pepaya Calina. Varietas 
ini telah dikenal oleh masyarakat dan sudah banyak dikembangkan untuk mengisi pasar domestik dan mempunyai peluang untuk diekspor (Arifiya, dkk., 2015).

Parameter kualitas buah pepaya yang menunjukkan tingkat ketuaan buah adalah kandungan pati, total padatan terlarut, kekerasan, keasaman dan warna kulit buah (Kingston, 2010).Tingkat ketuaan buah pada buah pepaya sangat menentukan kualitas buah pepaya saat matang hal ini sesuai dalam (Abu Goukh, dkk, 2010) yang menyatakan bahwa buah pepaya yang dipetik terlalu matang ataupun terlalu muda akan berdampak pada kualitasnya. Umur petik buah pepaya sangat menentukan kualitas pepaya selama penyimpanan, baik dalam hal perubahan kandungan pati, tingkat kekerasan, dan kadar air dalam buah pepaya tersebut (Arifiya, dkk, 2015). Namun, untuk mengetahui perubahan parameter kandungan pati, total padatan terlarut, dan kadar air memerlukan analisis yang bersifat destruktif. Sehingga untuk mengetahui perubahan selama penyimpanan, teknik analisis secara destruktif tidak mungkin dilakukan untuk memantau perubahan fisiologis pada sampel yang sama (Purwanto, dkk., 2015). Maka, pengembangan metode pendugaan kualitas buah pepaya secara nondestruktif, cepat, dan tepat sangat diperlukan dalam bidang agroindustri.

Nearinfrared (NIR) merupakan salah satu gelombang elektromagnetik yang telah banyak digunakan untuk menduga komponen kimia yang terdapat pada suatu produk pertanian.Metode spektroskopi NIR telah menjadi perhatian pada 10 tahun terakhir dan menjadi salah satu metode alternatif yang dapat dipertimbangkan untuk menggantikan analisis secara kimia (Chen dan Yen, 2007). Metode spektroskopi NIR merupakan sebuah metode nondestruktif, akurat, cepat, dan dapat menggantikan metode kimia yang mengkonsumsi waktu lebih lama.Spektroskopi NIR menawarkan pengukuran secara cepat (Saleh, 2012), dapat menghasilkan beberapa parameter sifat bahan dalam satu kali pengukuran serta dilakukan secara non destruktif.Pendugaan kualitas pepaya dengan spektroskopi NIR dapat dijadikan sebagai langkah awal untuk mengetahui kualitas buah pepaya secara nondestruktif.

Beberapa penelitian telah dilakukan untuk menduga kandungan kimia pada buah-buahan, antara lain pendugaankandungan pati pada buah mangga (Saranwong, dkk, 2004), prediksi kadar air pada buah kurma dengan menggunakan spectra NIR (Mireei, dkk,2010), dan pendugaan total padatan terlarut dengan spektroskopi NIR dilakukan (Bobelyn, dkk, 2010). Berdasarkan uraian di atas, maka penelitian inibertujuanuntuk memprediksi kandungan pati, total padatan terlarut, dan kadar airbuah pepaya IPB 9 selama penyimpanandengan spektroskopi NIR.Keluaran dari hasil penelitian ini diharapkan dapat dijadikan acuan untuk meningkatkan bidang agroindustri.

\section{Tinjauan Pustaka}

Pepaya IPB9 memiliki beberapa kelebihan, diantaranya memiliki diameter yang lebih kecil, bobot biji yang lebih kecil, dan mempunyai tebal daging buah yang lebih besar dibandingkan dengan pepaya IPB1, IPB2A, IPB3, IPB3A, IPB4, IPB7, dan IPB8.Besarnya nilai panjang, diameter, dan tebal minimum sampai maksimum daging buah pepaya varietas IPB9 secara berturut-turut adalah $23.78 \mathrm{~cm}, 9.63 \mathrm{~cm}$, dan $2.23-3.15 \mathrm{~cm}$ (Suketi, 2011).Pepaya merupakan buah klimaterik yang masih dapat mencapai puncak kematangan meski buah pepaya telah dipetik.

Hal itu, ditandai oleh senyawa pektin yang terdapat diantara dinding sel yang berfungsi sebagai perekat, kemudian terjadi proses degradasi pektin menjadi protopektin yang menyebabkan tekanan turgor dinding sel menurun dan menyebabkan buah menjadi lunak selama proses pematangan (Billy, dkk,2008). Oleh karena itu penentuan tingkat ketuaan buah pada saat dipetik merupakan salah satu faktor penting yang dapat mempengaruhi ketahanan buah dari kerusakan buah setelah dipetik. Mutu buah yang baik saat dikonsumsi 
akan diperoleh jika pemanenan buah dilakukan pada stadia kematangan yang tepat (Francois, dkk., 2009) sehingga diperoleh umur simpan yang lebih lama atau lebih pendek.

Near infared (NIR) adalah gelombang elektromagnetik dengan panjang gelombang 780$2500 \mathrm{~nm}$ yang terletak diantara gelombang cahaya tampak (visiblelight) dan cahaya inframerah (infrared).Spectroscopy adalah ilmu yangmempelajari antaraksi cahaya dengan atom dan molekul.Radiasi cahaya atauelektromagnetik dapat dianggap menyerupai gelombang (Creswell, dkk., 2005).Near infrared (NIR) merupakan salah satu instrument untuk menentukankomposisi kimia berdasarkan besarnya nilai pantulan gelombang (reflectance) danberdasarkan nilai absorban gelombang (log 1/R).Pada tahap awal diperlukan dataanalisis kimia dari laboratorium untuk mengetahui hubungan antara spektra NIRdan data hasil analisis kimia.Oleh karena itu diperlukan metode matematika, yangdibagi menjadi dua yaitu kalibrasi dan validasi.Jumlah sampel yang digunakanuntuk tahap kalibrasi dan validasi harus cukup banyak.Jumlah sampel untuk tahapkalibrasi harus lebih banyak daripada untuk tahap validasi.Validasi bertujuan menguji ketepatan pendugaan komposisi kimia persamaan regresi kalibrasi yang telah dibangun.Model kalibrasi dikatakanbaik (akurat), jika nilai $R 2$ (0.8-1), $R P D \geq 2$, perbedaan nilai $S E C$ dan SEP kecil (Karoui, dkk., 2006).

Informasi yang terkandung dalam spektra NIR dapat diambil dengan menggunakan berbagai teknik analisis multivariable yang disebut juga dengankemometrik.Tujuan dari teknik ini adalah untuk membuat model kalibrasi yangmampu memprediksi karakteristik sampel yang tidak diketahui.Teknik analisismultivariable tersebut dibagi menjadi dua jenis berdasarkan hubungan linearitasdan non-linearitas parameter.Partial Least Square (PLS), principal componentsregression (PCR), dan multiple linear regression (MLR).

Partial Least Square (PLS) merupakan suatu metode analisis multivariableuntuk membangun model prediksi dari variabel-variabel yang banyak danmemiliki kolinearitas yang tinggi, atau dengan kata lain metode ini berguna untukmemprediksi variable tak bebas (dependent) dari sejumlah besar variable bebas(independent), memiliki stuktur sistemik linier ataupun non linier (Tobias, 2011). Metode PLS diperoleh secara iterative dan tidak memiliki formula tertutup untukmencari ragam koefisien regresinya.Pada setiap iterasi dalam PLS keragamanpeubah-peubah $\mathrm{x}$ dan keragaman peubah-peubah $\mathrm{y}$ saling mempengaruhikombinasi linier kelompok peubah $\mathrm{x}$ dan begitu sebaliknya.

Metode PLS telah banyak digunakan sebagai metode olah data spektra NIR, antara lain prediksi total padatan terlarut(TPT) dan kekerasan sebagai parameter kualitas buah saat di pohon hinggapascapanen (Marin, dkk, 2009). Hasilnya, TPT dan kekerasan dapat diprediksi dengan tingkat akurasi tinggi, dengan nilai $R^{2}$ total padatan terlarut 0.89 danuntuk kekerasan memiliki $R^{2} 0.86$. Prediksikadar air dan protein pada buah kurma mazafati menggunakan metode PLS dapat dilakukan dengan baik (Mireei, dkk, 2010)padapanjang gelombang 900$1.700 \mathrm{~nm}$ dan $1.332-1641 \mathrm{~nm}$ dengan nilai $R^{2} 0.98$ untuk kadr air dan $R^{2} 0.97$ untuk protein.

Pada penelitian (Suhandy, dkk, 2008) pengukuran bahan kering dari buah mangga yang masih di pohon dengan spektroskopi NIR dengan metoda PLSdiperoleh koefisien korelasi $(r)$ sebesar 0.93 dan standar eror prediksi 0.89 denganbias 0.12 . Pengolahan data dengan metoda PLS juga dilakukan untuk mengetahui persentase bahan kering pada dengan nilai selisih SEP dan SEC sebesar 0.81 (Francois, dkk., 2009).

\section{Metodologi Penelitian}

Penelitian ini menggunakan pepaya IPB9 sebanyak 60 buah dan gas etilen murni 50ppm. Alat yang digunakan adalah, oven, cawan, chamber kaca kedap udara, fan berukurankecil, termometer, timbangan digital, kamera digital, seperangkat alat spektofotometer NIRFlex N500 (fiber optic solids) dengan panjang gelombang 1000-2500 nm, dan NIRCal 5.2 (Buchi Labortechnik AG, Flawil, Switzerland) dengan menggunakan algoritma PLS. 
Penelitian ini dilakukan pada bulan Januari hingga Juni 2014 di laboratorium TPPHP, Departemen Teknik Mesin dan Biosistem, Institut Pertanian Bogor. Sampel yang digunakan sebanyak 60 buah, buah pepaya digunakan diperoleh dari kebun Pusat Kajian Hortikultura Tropis (PKHT) dipetik secara langsung, kemudian dibersihkan, dibungkus kertas, dan setelah itu dimasukkan ke dalam kardus karton lalu dibawa ke laboratorium TPPHP dengan mobil. Sampai di laboratorium pepaya langsung dibuka, kemudian disortasi dan dibersihkan serta diberi label.

Penelitian ini dilakukan 3 kali ulangan dengan menggunakan buah pepaya IPB 9 yang berbeda, dan dilakukan tiga kali pengukuran pada masing-masing buah pepaya yaitu pangkal, tengah, dan ujung. Pengukuran pertama dilakukan sesaat setelah panen (sebelum pemeraman) dengan menggunakan spektroskopi NIR. Parameter yang diukur adalah kandungan pati, total padatan terlarut, dan kadar air, masing-masing buah pepaya diukur pada tiga titik yaitu pangkal, tengah, dan ujung.

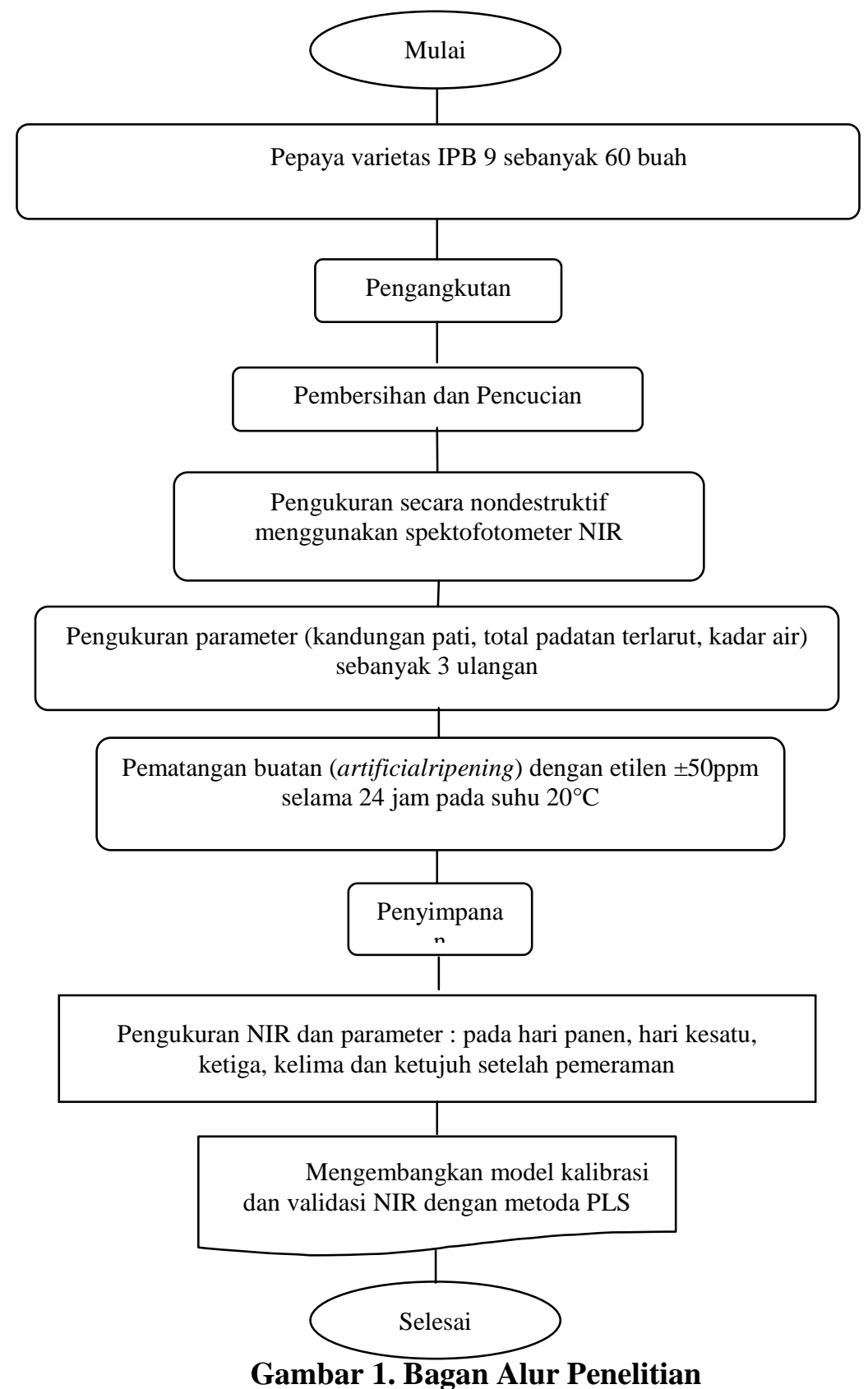


Pengukuran pertama adalan dengan spektofotometer NIR, kemudian buah pepaya dikupas tipis kulitnya dan bagian dalamnya dibuang hingga sekitar 3-5mm ketebalannya, untuk pengukuran kadar air. Pengukuran kadar air menggunakan metode gravimetric menggunakan oven pada suhu $105^{\circ} \mathrm{C}$ selama $25 \mathrm{jam}$, persamaan yang digunakan terlihat pada persamaan (1).

$$
k . a(\%)=\frac{m_{0}-m_{1}}{m_{0}} \times 100 \%
$$

Keterangan : k.a : kadar air, $\mathrm{m}_{0}$ : massa awal, $\mathrm{m}_{1}$ : massa akhir

Setelah pengkuran pertama selesai, maka buah pepaya yang lain dilakukan pemeraman (artificialripening) dengan menggunakan gas etilen sebanyak 50ppm (Syska, 2006) pada suhu $20^{\circ} \mathrm{C}$ selama 24 jam dalam chamber kaca tertutup dan menggunakan kipas kecil untuk memutar udara dalam chamber. Pengamatan selanjutnya dilakukan pada hari kesatu, ketiga, kelima, dan ketujuh setelah pemeraman.

Analisa data menggunakan software NIRCal 5.2 (Buchi Labortechnik AG, Flawil, Switzerland) dengan menggunakan algoritma PLS. Data diolah dengan dan tanpa pra perlakuan data spectra, sehingga akan diperoleh data terbaik dengan atau tanpa pra perlakuan data spectra.Pra perlakuan yang digunakan pada analisis data ini adalah multiple scatter correction (msc) dan turunan pertama ( $\mathrm{dg} 1)$.Multiple scatter correction (msc) merupakan salah satu teknik normalisasi yang sering digunakan yang bertujuan untuk mengurangi bias yang disebabkan perbedaan ukuran fisik dari sampel, sehingga baik digunakan untuk memperoleh kalibrasi terbaik. Sedangkan turunan pertama (dg1) digunakan untuk meningkatkan aspek visual dari spektra NIR lebih mendalam tanpa menghapus informasi yang ada, sehingga pra perlakuan ini baik digunakan untuk memperoleh kalibrasi terbaik dari masing-masing parameter.

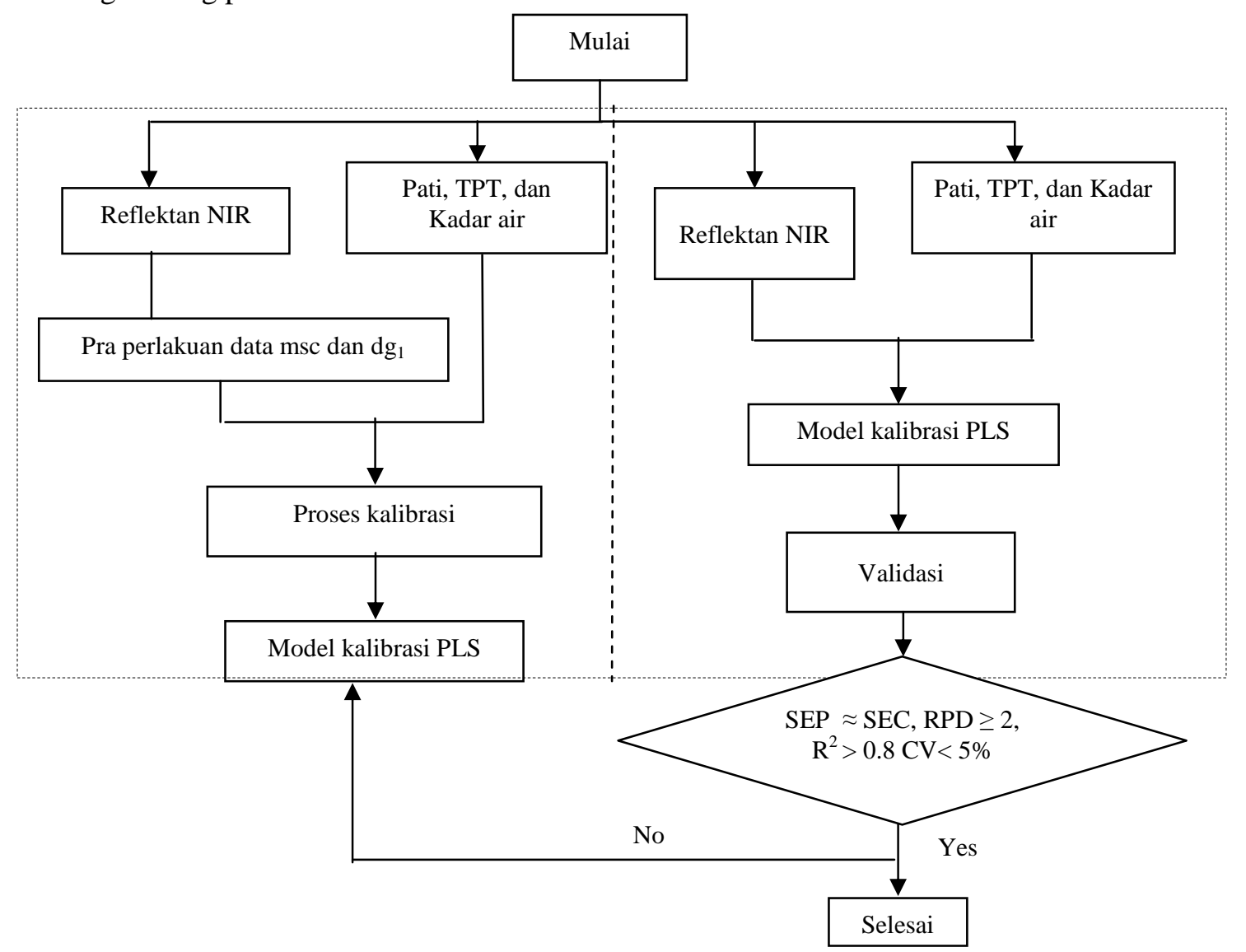

Gambar 2. Alur Analisis Data 


\section{Hasil dan Pembahasan}

\section{Karakteristik Gelombang Spektra NIR Pepaya Var. IPB9}

Prinsip pengukuran spektra NIR adalah dengan memancarkan sinar lampu halogen ke sampel, sinar tersebut diterima sebagai energi yang memicu terjadinya getaran dan regangan pada kelompok ikatan atom $\mathrm{O}-\mathrm{H}, \mathrm{N}-\mathrm{H}$, dan $\mathrm{C}-\mathrm{H}$, dimana ikatan atom $\mathrm{O}-\mathrm{H}, \mathrm{N}-\mathrm{H}$, dan $\mathrm{C}-\mathrm{H}$ merupakan komponen utama pembentuk kandungan organik. Sebagian energi yang diberikan akan diserap untuk melakukan getaran dan regangan dan sebagian lainnya akan dipantulkan. Energi yang dipantulkan akan diterima oleh detector sebagai data frekuensi getaran dalam bentuk analog, selanjutnya data analog tersebut akan ditransformasi dengan menggunakan metode transformasi fourier sehingga menjadi kurva spektra reflektan seperti terlihat pada Gambar 3.

Spektra asli reflektan (R) dari pepaya varietas IPB9 memperlihatkan spektra yang lebar dari 1000-2500 nm dengan beberapa puncak dan lembah spektra.lembah dan puncak spektra tersebut sangat dipengaruhi oleh komponen kimia dari buah pepaya varietas IPB9 yang dianalisis. Selain itu, karakteristik fisik bahan juga mempengaruhi fitur spektra NIR (Blanco dan Villaroyya, 2002). Kandungan bahan pada buah pepaya varietas IPB9 berhubungan erat dengan penyerapan radiasi NIR.

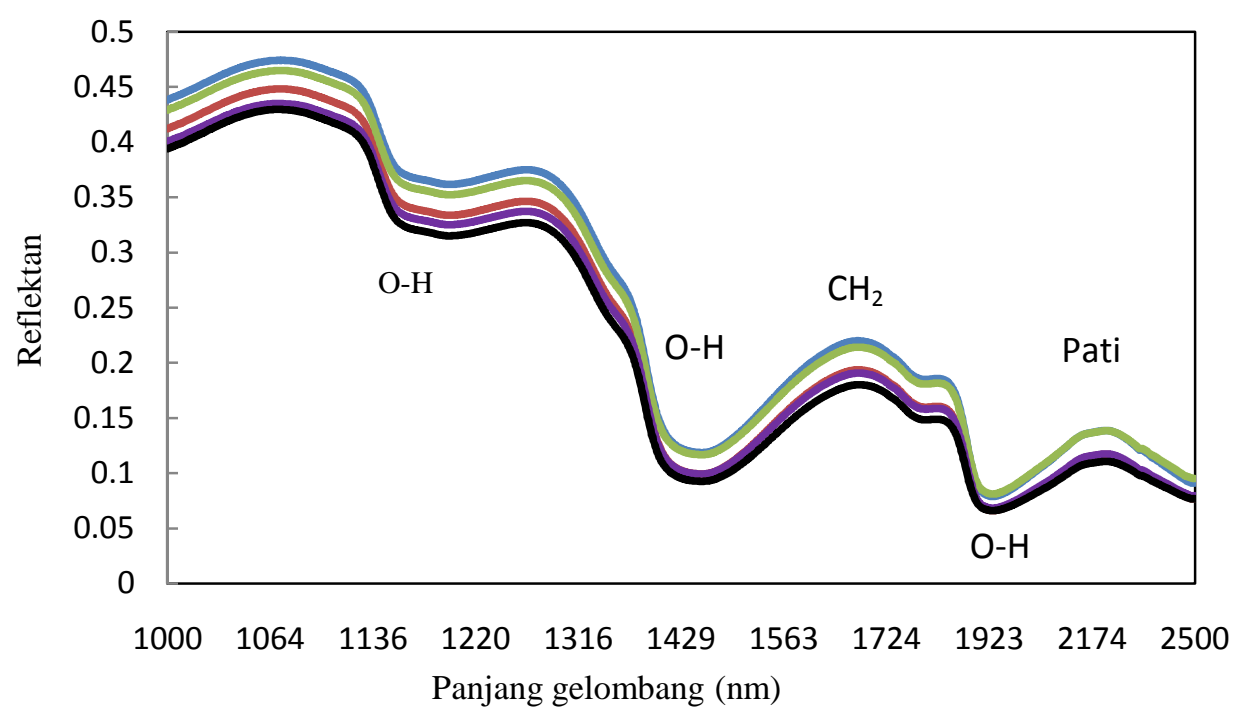

\section{Gambar 3. Spektra Original Reflektan NIR}

Karakteristik spektra reflektan terlihat pada Gambar 3 yang menunjukkan adanya beberapa lembah pada grafik reflektan NIR.Hal ini terjadi karena terdapat ikatan O-H (O-H.str first overtone) pada panjang gelomabang tersebut (Osborne, dkk, 1993). Lembah pemantulan (reflektan) terjadi pada panjang gelombang $1756 \mathrm{~nm}-1780 \mathrm{~nm}$, dimana ikatan atom $\mathrm{C}-\mathrm{H}$ pada panjang gelombang tersebut menunjukkan adanya kandungan $\mathrm{CH}_{2}$ dan selulosa. Kandungan pati (starch) terdapat pada panjang gelombang $1450 \mathrm{~nm}, 2461 \mathrm{~nm}, 2488 \mathrm{~nm}$ dan $2500 \mathrm{~nm}$. Kandungan pati pada panjang gelombang $1450 \mathrm{~nm}$ ini sulit terlihat karena saling berhimpit dengan kandungan air pada panjang gelombang yang sama, kandungan pati ini memiliki ikatan O-H str. first overtone (Osborne, dkk., 1993).

Dari Gambar 3 juga terlihat bahwa spektra ulangan pertama terletak paling bawah begitu selanjutnya sampai ulangan kelima, ulangan ini seiring dari umur petik yang lebih muda berturut-turut naik ke atas seiring dengan semakin tua umur petik buah pepaya varietas IPB9.Hal ini menunjukkan bahwa pada pepaya dengan umur petik yang lebih mudah, maka daya serap buah terhadap gelombang NIR semakin tinggi sehingga nilai reflektan menjadi lebih kecil. Pada pepaya varietas IPB9 yang masih muda memiliki kadar air yang lebih besar 
jika dibandingkan dengan buah pepaya yang sudah matang fisiologi dan matang berturutturut sebesar $94.3 \%, 94.1 \%, 93.2 \%, 92.6 \%$, dan $91.9 \%$. Dengan demikian air memiliki daya serap yang tinggi terhadap gelombang elektromagnetik NIR dibandingkan dengan komponen pepaya lain. Hal ini juga terlihat dari spektra reflektan pada Gambar 3 yang menunjukkan lembah pada panjang gelombang yang membaca adanya kandungan air dalam buah pepaya.

\section{Prediksi Kandungan Pati Pepaya Var. IPB9 dengan Spektroskopi NIR}

Kalibrasi dan validasi spektra NIR untuk memprediksi kandungan pati sampel buah pepaya varietas IPB9 dikembangkan berdasarkan korelasi data spektra reflektan NIR dengan data pati hasil pengukuran secara destruktif.Data yang dianalisis adalah data sampel buah pepaya varietas IPB9 berjumlah 60 buah.Pengukuran dilakukan sesaat setelah panen dan selama penyimpanan.

Berdasarkan nilai komponen evaluasi diketahui bahwa kandungan pati pada sampel buah pepaya varietas IPB9 dengan umur petik yang berbeda memiliki korelasi dengan spektra reflektan NIR terbaik pra perlakuan kombinasi (msc dan dg1). Hal ini ditunjukkan dari perolehan nilai $R$ sebesar 0.90 (Tabel 3), senada dengan hasil penelitian (Saranwong, dkk, 2004) pada buah mangga kandungan pati dapat diprediksi oleh spektroskopi NIR dengan nilai $R$ sebesar $0.93, R^{2}$ sebesar 0.81 (Tabel 1), sedangkan hasil penelitian (McGlone, dkk., 2002) prediksi kandungan pati pada buah apel diperoleh nilai $R^{2}$ sebesar 0.66.

Pada penelitian ini diperoleh selisih nilai SEP dan SEC sebesar 0.01 (Tabel 1) sama halnya dengan hasil penelitian (McGlone, dkk, 2002), sedangkan pada buah mangga selisih nilai SEP dan SEC sebesar 0.13 (Saranwong, dkk,2004). Nilai koefisien keragaman (CV) yang dihasilkan pada penelitian ini sebesar 10.95\%, sedangkan hasil (Saranwong, dkk, 2004) nilai $C V$ sebesar 4\% dan hasil (McGlone, dkk., 2002) nilai $C V$ sebesar 90\%. Nilai koefisien keragaman (CV) ini sangat ditentukan dari keragaman sampel yang digunakan pada penelitan.

Tabel 1. Komponen Evaluasi Hasil Kalibrasi dan Validasi NIR terhadap Kandungan Pati Buah Pepaya Varietas IPB9 dengan Metode PLS

\begin{tabular}{lcccccc}
\hline \multirow{2}{*}{ Perlakuan } & \multicolumn{5}{c}{ Parameter } \\
\cline { 2 - 7 } & $R^{2}$ & $R$ & $S E C(\%)$ & SEP $(\%)$ & $C V(\%)$ & $R P D$ \\
\hline Tanpa * & 0.44 & 0.66 & 0.28 & 0.28 & 18.40 & 1.29 \\
Dengan ** & 0.81 & 0.90 & 0.17 & 0.16 & 10.95 & 2.15 \\
\hline
\end{tabular}

*: tanpa pra perlakuan

**: dengan pra perlakuan msc, dg1

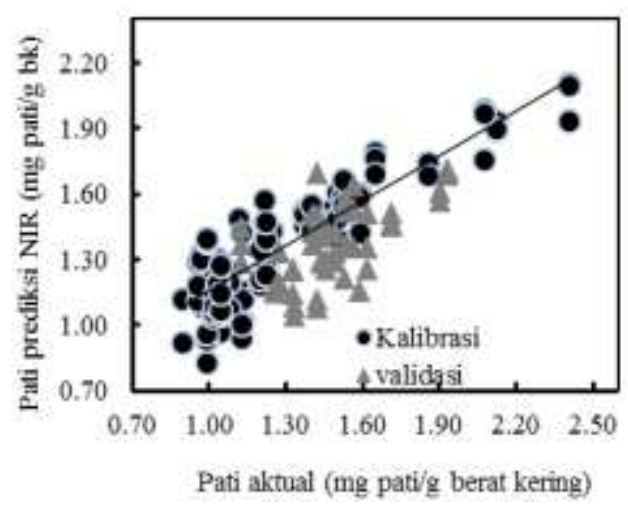

Gambar 4. Plot Kandungan Pati Aktual dan Prediksi NIR dengan pra Perlakuan Kombinasi (msc,dg1) 
Perbedaan hasil komponen evaluasi NIR sangat dipengaruhi oleh jumlah dan dan jumlah spektra NIR yang digunakan. Pada penelitian (McGlone, dkk, 2002) data spektra yang digunakan sebanyak 181, hampir sama dengan data spektra pada penelitian ini. Sedangkan pada penelitian (Saranwong, dkk, 2004) sampel yang digunakan untuk pengukuran secara nondestruktif dengan NIR sebanyak 346 buah mangga, sehingga data spektra NIR yang digunakan hampir 1000 data. Sehingga komponen evaluasi yang dihasilkan oleh (Saranwong, dkk., 2004) lebih baik dari hasil penelitian ini.

\section{Prediksi TPT Pepaya Varietas IPB9 dengan Spektroskopi NIR}

Berdasarkan hasil penelitian menunjukkan bahwa nilai total padatan terlarut buah pepaya pada umur petik yang berbeda memiliki nilai total padatan terlarut yang berbeda pula. Hal ini dikarenakan pada umur petik yang lebih tua berada pada tahap pematangan dan mendekati puncak klimakterik. Sehingga laju respirasi pada buah masak lebih besar dibandigkan dengan buah yang masih muda, seiring meningkatnya laju respirasi maka metabolisme buah yang ditandai oleh terhidrolisisnya pati menjadi gula-gula sederhana meningkat. Oleh karena itu, buah dengan umur yang berada pada tahapan pematangan memiliki nilai total padatan terlarut tertinggi dan memiliki waktu yang lebih cepat untuk mencapai puncak klimakterik.

Tabel 2. Komponen Evaluasi Hasil Kalibrasi dan Validasi NIR terhadap Total Padatan Terlarut Buah Pepaya Varietas IPB9 dengan Metode PLS

\begin{tabular}{ccccccc}
\hline \multirow{2}{*}{ Perlakuan } & $R^{2}$ & $R$ & $S E C(\%)$ & $S E P(\%)$ & $C V(\%)$ & $R P D$ \\
\cline { 2 - 7 } & 0.79 & 0.89 & 0.13 & 0.14 & 5.41 & 2.16 \\
Tanpa * & 0.81 & 0.90 & 0.124 & 0.123 & 4.85 & 2.27 \\
Dengan ** & \multicolumn{7}{c}{ Parameter } \\
*: tanpa pra perlakuan & & & &
\end{tabular}

Hasil kalibrasi dan validasi dengan metode PLS terbaik dengan pra perlakuan msc yang dievaluasi berdasarkan nilai $R^{2}, r, S E P, S E C, R P D$, dan $C V$. Berdasarkan nilai komponen evaluasi tersebut diketahui bahwa total padatan terlarut buah pepaya varietas IPB 9 selama penyimpanan memiliki korelasi dengan spektra reflektan NIR. Hal ini ditunjukkan dari perolehan nilai koefisien korelasi $(r)$ model kalibrasi sebesar 0.90. Nilai $R^{2}$ yang diperoleh pun baik yaitu sebesar 0.81 yang artinya $81 \%$ kontribusi total padatan terlarut aktual hasil pengukuran terhadap variasi total padatan terlarut prediksi NIR. Selisih nilai SEP dan SEC sebesar 0.001 serta nilai CV $<5 \%$ yaitu CV $4.85 \%$, dan nilai RPD > 2 yang menunjukkan akurasi dan kestabilan model baik untuk menduga nilai total padatan terlarut dengan spektroskopi NIR (Tabel 2).



Gambar 5. Plot Total Padatan Terlarut dan Prediksi NIR dengan pra Perlakuan msc

Hasil penelitian (Syaefullah, 2008) yang melakukan penelitian pada buah pepaya vairetas IPB 1 diperoleh nilai koefisien korelasi $(r)$ sebesar 0.98 . Pada penelitian ini nilai $R^{2}$ yang 
diperoleh pun baik yaitu sebesar 0.81 (Tabel 2), sedangkan hasil penelitian (McGlone, dkk, 2002) prediksi total padatan terlarut pada buah apel diperoleh nilai $R^{2}$ sebesar 0.63 dan hasil penelitian. Nilai $R^{2}$ berkisar dari $0.66-0.88$ dari 6 varietas apel yang digunakan pada penelitian (Bobelyn, dkk., 2010).Nilai CV yang dihasilkan kurang dari 5\% sebesar 4.85\%, sedangkan hasil dari penelitian (McGlone, dkk, 2002) diperoleh nilai CV untuk total padatan terlarut sebesar $8 \%$.

\section{Prediksi Kadar Air Pepaya Var. IPB9 dengan Spektroskopi NIR}

Berdasarkan hasil penelitian menunjukkan bahwa kadar air buah pepaya pada umur petik yang berbeda memiliki kadar air yang berbeda pula. Pada umur petik yang muda memiliki kadar air terbesar dan menurun seiring dengan proses pematangan buah pepaya. Hal ini dikarenakan pada umur petik yang lebih tua berada pada tahap pematangan dan mendekati puncak klimakterik, sehingga seiring meningkatnya laju respirasi dapat mempercepat proses penguapan air dari dalam buah sebagai hasil dari proses respirasi. Oleh karena itu, buah dengan umur petik yang lebih tua memiliki kadar air yang lebih rendah, jika dibandingkan dengan buah yang masih muda. Selama proses pematangan, kadar air buah pepaya dari umur petik yang berbeda pada umumnya mengalami penurunan seiring dengan proses pematangan.

Pada Gambar 3 terlihat bahwa lembah terjadi pada panjang gelombang $1190 \mathrm{~nm}, 1450 \mathrm{~nm}$, dan $1940 \mathrm{~nm}$ yang mencerminkan penyerapan energi oleh ikatan O-H. Sampel yang dikenai radiasi NIR akan menerima energi yang memicu terjadinya getaran dan regangan pada kelompok ikatan atom $\mathrm{O}-\mathrm{H}, \mathrm{N}-\mathrm{H}$, dan $\mathrm{C}-\mathrm{H}$ yang merupakan komponen utama pembentuk senyawa organik. Sebagian energi akan diserap dan sebagian lainnya akan dipantulkan, energi yang dipancarkan ke bahan organik sekitar $4 \%$ akan dipantulkan kembali oleh permukaan luar (regular refleksion) dan $96 \%$ akan masuk ke dalam bahan kemudian mengalami penyerapan, pemantulan, penyebaran, dan penerusan cahaya.

Selain itu pada Gambar 6 terlihat bahwa dengan pra perlakuan dg1 sebaran data lebih terkumpul pada garis linear antara nilai kadar air prediksi NIR dan kadar air aktual. Nilai $R^{2}$ yang diperoleh sebesar 0.71, selisih nilai SEP dan SEC sebesar 0.01 (Tabel 3), dan nilai $C V$ yang dihasilkan jauh lebih rendah dari $5 \%$ sebesar $0.43 \%$. Sedangkan hasil penelitian (Bampi, dkk, 2013) yang menduga kadar air dalam biodiesel dengan menggunakan NIR memperoleh hasil yang baik dengan nilai $R^{2} 0.993$.

Tabel 3. Komponen Evaluasi Hasil Kalibrasi dan Validasi NIR Terhadap Kadar Air Buah Pepaya Varietas IPB 9 dengan Metode PLS

\begin{tabular}{ccccccc}
\hline \multirow{2}{*}{ Perlakuan } & \multicolumn{7}{c}{ Parameter } \\
\cline { 2 - 7 } & $R^{2}$ & $R$ & $S E C(\%)$ & $S E P(\%)$ & $C V(\%)$ & $R P D$ \\
\hline Tanpa * & 0.63 & 0.80 & 0.04 & 0.05 & 0.47 & 1.65 \\
Dengan ** & 0.71 & 0.84 & 0.03 & 0.04 & 0.43 & 1.85 \\
\hline *: tanpa pra perlakuan & \multicolumn{7}{c}{} \\
**: dengan pra perlakuan dg1 & & & &
\end{tabular}

Hal tersebut dikarenakan pada penelitian ini sampel yang digunakan terbatas, sehingga spektra yang digunakan pada kalibrasi dan validasi hanya 180 spektra.Pada penilitian (Mireei, dkk, 2010) berhasil memprediksi kadar air pada buah kurma mazafati menggunakan spektra NIR pada panjang gelombang $900-1.700 \mathrm{~nm}$ dan $1.332-1641 \mathrm{~nm}$ dengan metode olah data PLS. Hasilnya, kadar air dapat diprediksi dengan sangat baik, dengan model kalibrasi untuk kadar air memiliki nilai $R^{2}=0,98$. Nilai $R P D<2$ pada penelitian ini, sehingga model kalibrasi yang dihasilkan cukup baik untuk memprediksi kadar air dengan spektroskopi NIR. 


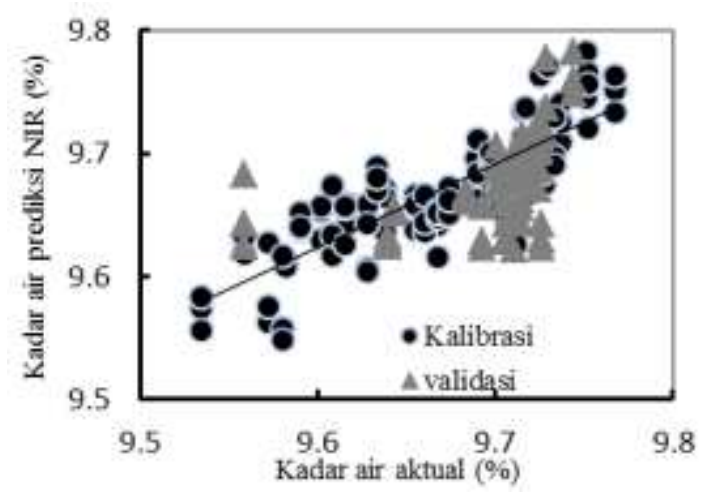

Gambar 6. Plot Kadar Air Aktual dan Prediksi NIR dengan pra Perlakuan dg1

\section{Simpulan dan Saran}

1) Kandungan pati pepaya varietas IPB 9 dapat diprediksi dengan baik oleh spektroskopi NIRdengan pra perlakuan kombinasi $m s c$ dan $\mathrm{dg}_{1}$ yang ditunjukkan oleh model yang dihasilkan dengan nilai $R, S E C, S E P, C V$, dan $R P D$ berturut-turut sebesar $0.90,0.17 \%$, $0.16 \%, 10.95 \%$, dan 2.15 .

2) Total padatan terlarut pepaya varietas IPB 9 dapat diprediksi dengan baik oleh spektroskopi NIR dengan pra perlakuan msc diperoleh nilai $R, S E C, S E P, C V$, dan $R P D$ berturut-turut sebesar 0.90, $0.124 \%, 0.123 \%, 4.85 \%$, dan 2.27 .

3) Kadar air pepaya varietas IPB 9 dapat diprediksi cukup baik oleh spektroskopi NIR dengan pra perlakuan dg1 diperoleh nilai $R, S E C, S E P, C V$, dan $R P D$ berturut-turut sebesar $0.84,0.03 \%, 0.04 \%, 0.43 \%$, dan 1.85 .

4) Perlu dilakukan analisis parameter - parameter lain yang berkaitan dengan proses pematangan buah pepaya selama penyimpanan

5) Perlu dilakukan upayalain untuk meningkatkan umur simpan pepaya IPB 9.

\section{Daftar Pustaka}

Abu Goukh, A.B.A., Shattir, A.E.T., \&Mahdi, E.F.M. (2010). Physico-chemical changes during growth and development of Papaya Fruit. II : Chemical changes. Agriculture and Biology Journal of North America, Vol 1 No.5 Tahun 2010.871-877.

Arifiya, N., Purwanto, Y.A., \& Budiastra, I.W. (2015).Analisis perubahan kualitas pascapanen pepaya varietas IPB 9 pada umur petik yang berbeda.Jurnal Keteknikan Pertanian, Vol 3 No. 1 Tahun 2015.41-48.

Bampi, M., Scheer, A.P., \&Castilhos, F. (2013). Application of near infrared spectroscopy to predict the average droplet size and water content in biodiesel emulsions. FuelJournal,Vol 113 Tahun 2013.546-552.

Billy, L., MBilly, L., Mehinagic, E., Royer, G., Renard, C.M.G.C., Arvisenet, G., Prost, C., \&Jourjon F. (2008). Relationship between texture and pectin composition of two applecultivars during storage.J. Postharvest Biology and Technology, Vol.47 Tahun 2008. 315-324

Blanco, M dan Villarroya, I. (2002). NIR spectroscopy: a rapid-response analitycal tool. Trend in Analitical Chemistry, Vol21Tahun 2001.240-250.

Bobelyn, E., Serban, A.S., Nicu, M., Lammertyn, J., Nicolai, B.M., \&Saeys, W. (2010). Postharvest quality of apple predicted by NIR-spectroscopy: Study of the effect of biological variability on spektra and model performance. Journal Postharvest Biology and Technology, Vol 55 Tahun 2010.133-143.

Cen, H dan Yen He.(2007). Theory and application of near infrared reflectance spectroscopy in determination of food quality.Trends in Food Science \& Technology, Vol 18 Tahun 
Creswell, C.J., Runquist, O.A., \& Campbell, M.M. (2005) .Analisis spektrum senyawa organik.Bandung: Penerbit ITB.

Francois, I.M., Marien, E., Brijs, K., Coppin, P., \& Proft, M.D. (2009). The use of Vis/NIR spectroscopy to predict the optimal root harvesting date of chicory (Cichorium intybus L.).J Postharvest Biology and Technology.Vol.53 Tahun 2009.77-83.

Karoui, R., Mouazen, A.M., Dufor, Eee, Pillonel, L., Schaller, E., De Baerdemaeker J., Bosset, J.O. (2006). Chemichal characterization of European emmental cheeses by near infrared spectroscopy using chemometric tools. International Dairy Journal.Vol.16 Tahun 2006.1211-1217.

Kingston, C.M. (2010). Maturity indices for apple and pear. In: Janick, Journal (Ed.), Horticultural Reviews, Vol. 13. John Wiley \& Sons, Inc., Oxford, Tahun 2010.407-422.

Marin, D.P., Sanchez, M.T., Paz, P., Soriano, M.A., Guerrero, J.E., Varo, A.G. (2009). Nondestructive determination of quality parameters in nectarines during ontree ripening and postharvest storage.J Postharvest Biology and Technology.Vol.52 Tahun 2009.180188.

McGlone VA, Jordan RB, Martinsen PJ.(2002). VIS/NIR estimation at harvest of pre and post storage quality indices for 'Royal Gala' apple.Journal postharvest Biology and Technology, Vol 25 Tahun 2002.135-144.

Mireei, S.A., Mohtasebi, S.S., Massudi, R., Rafiee, S., Arabanian, S., \& Berardinelli, A. (2010).Non-destruktif measurement of moisture and soluble solids content of Mafazati date fruit by NIR spectroscopy.Australian Jurnal of Crop ScienceVol 4 No. 3 Tahun 2010.175-179.

Osborne, B.G. (1993). Near infrared spectroscopy in food analysis. Encyclopedia of Analical Chemistry. Chichester: John Willey \& Sons Ltd.

Purwanto, Y.A., Budiastra, I.W., Darmawati, E., \& Arifiya, N. (2015).Measurement of starch and soluble solid content in papaya using near infrared spectroscopy.Journal of Chemical and Pharmaceutical Research Vol. 7 No. 6 Tahun 2015.112-116.

Saleh, B. (2012). Biochemical and genetic variation of some Syrian wheat varieties using NIR, RAPD and AFLPs Techniques.Journal of Plant Biology Research,Vol 1 Tahun 2012.1-11.

Saranwong, S., Sornsrivichai, J., \&Kawano, S. (2004). Prediction of ripe-stage eating quality of mango fruit from its harvest quality measured nondestructively by near infrared spectroscopy.Journal postharvest Biology and TechnologyVol. 31 Tahun 2004137-145.

Suhandy, D., Prabawati, S., Yulianingsih, \& Yatmin.(2008). Penentuan bahan kering buah mangga secara intact menggunakan near infrared spectroscopy.J Pascapanen.Vol. 5 No.2 Tahun 2008.10-17.

Suketi, K. (2011). Studi morfologi bunga, penyerbukan, dan perkembangan buah sebagai dasar pengendalian mutu buah Pepaya IPB.Disertasi. Bogor. Institut Pertanian Bogor.

Syaefullah, E. (2008). Optimasi Keadaan Penyimpanan Buah Pepaya Sebelum Pemeraman dengan Algoritma Genetika.(Disertasi).Institut Pertanian Bogor. Bogor.

Syska, K. (2006). Kajian Pengaruh Suhu dan Konsentrasi Etilen terhadap Perubahan Fisiologi dan Mutu Buah Pepaya Varietas IPB 1.(Tesis).Departemen Teknik Mesin dan Biosistem.Institut Pertanian Bogor. Bogor.

Tirkey, B., Pal, U.S., Bal, L.M., Sahoo, N.R., Bakhara, C.K., \&Panda, M.K. (2014). Evaluation of physic-chemical changes of fresh-cut unripe pepaya during storage. Journal Food Packanging and Self Life, Vol. I Tahun 2014.190-197.

Tobias, R.D. (2011). An introduction to partial least square regression. SAS Institute Inc., Car, NC. http://support.sas.com/app/papers/pls.pdf [diakses 7 agustus 2014]. 